\title{
\% \\ THE EFFECT OF SPEECH ACT FUNCTIONS ON THE DEVELOPMENT OF EFL LEARNERS' HIGH ORDER THINKING SKILLS
}

\author{
Eman H. Saleh \\ E-Mail Id: emnslh9980@gmail.com
}

English Language Teacher and Coordinator at Ministry of Education

Teaching Diploma of Teaching English- Lebanese University- Faculty of Pedagogy, Lebanon

Masters in Applied linguistics -Lebanese University- Faculty of Letters and Human Sciences, Lebanon PhD. Candidate in Applied Linguistics -Lebanese University- Faculty of Letters and Human Sciences, Lebanon

\begin{abstract}
In the globalized age, English language becomes lingua franca. Therefore, there should be convention between interlocutors on the intended meaning of utterances to avoid the misunderstanding of the speech acts used in cross-cultural speech communities. Speech act theory is a pragmatic theory which asserted that words are not just uttered words, but also they perform action. However, understanding and producing speech acts efficiently and appropriately in contextualized situations demands high order thinking skills such as to remember, understand, apply, analyze, evaluate, and create. EFL learners have many pragmatic problems that hinder using high order thinking skills in communication. Thus, an experimental research design with pre/posttest to control and experiment groups was done to cycle III students $(N=60)$ from the Lebanese Public Schools. The results revealed that analyzing the appropriate and relevant meaning of speech acts developed high order thinking skills, and thus they became proficient communicators in all language skills. Therefore, all EFL teachers, material designers, and learners are advised to incorporate speech act functions to develop high order thinking skills and create creative learners who are able to translate their intentions appropriately and efficiently in English in the global world.
\end{abstract}

\section{INTRODUCTION}

Nowadays, no one neglects the effect of globalization and internalization on the development of English language. English becomes the password of interaction and the entrance ticket for international communication (Kasper, 1995). Patel and Jain (2008) said that English is the mother tongue for nearly 320 million people and 200 million use it as second language. Hence, no other language in the world is spreading and developing like English language as Kashru and Smith (2008) stated .

As a result, English Language becomes lingua Franca which means, "language is adopted as a common language between speakers whose native languages are different " (Oxford Dictionary, 2016). Crystal (2003) said that English nowadays is used in three contexts: the inner circle (used in mother language in Britain, America, Australia and Canada), the outer circle (used as second language in the official authorities such as in Japan, China, and Mexico), and the expanding circle (used as foreign language in all the countries in the world). This wide spread of English language necessitates use high order thinking skills to communicate effectively and appropriately in a creative and analytical way.

However, the wide spread of English leads sometimes to miscommunication problems. Kashru and Smith (2008) said that English language has changed to "Englishes" because there are a lot of varieties of English due its uses in the cross cultural communities. Therefore, it's essential to find common rules that enable English users in the world to use language appropriately and effectively in various cross-cultural context. Speech act theory is a pragmatic theory that studies the functional use of language in the society such as questioning, thanking, apologizing, refusing, and complementing. Teaching speech acts to EFL learners can help them to use the same linguistic utterance in the appropriate cultural situation and minimize the probability of appearing rude or impolite, which leads to many conflicts in the global world.

Therefore, the purpose of this research is to highlight the importance of teaching speech act functions to EFL learners to develop their high order thinking skills, and thus to develop their communicative skills. High order thinking skills include critical, logical, reflective, metacognitive, and creative thinking. They are activated when individuals encounter unfamiliar problems, uncertainties, questions, or dilemmas. Successful applications explanations, decisions, performances, and products within the context of available knowledge and experience promote continued growth intellectual skills (King et al. 1998).

\subsection{The Research Problem}

The Lebanese EFL curriculum gains its importance as it adopts the communicative approach. It is a universal approach that aims to develop the learners' communicative competence to receive and produce English texts 


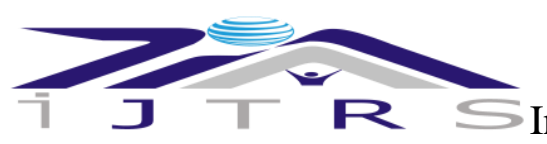

International Journal of Technical Research \& Science

(Ghaith and Shaaban, 1999). Actually, although the curriculum's objective is to foster communication; students have miscommunication problems.

However, this curriculum, in this way, didn't develop learners' thinking skills. The World Economic Forum international presented an international study PISA test to evaluate thinking analysis strategies for students in 2015. Unfortunately, it revealed that Lebanon got the $68^{\text {th }}$ rank among 73 countries shared in this test (Ayash, 2016). Second, English language level in the official schools is lower than private sector as Bask Study revealed (Al Zoughbi, 2013). In addition to that, although the new curriculum of English has many advantages such as application of content-based approach, use of cooperative learning, and inclusion of thinking skills, study skills, and cultural awareness, the problem lies in application of these objectives in purposeful tasks as revealed by Lebanese Association for Educational Studies (2003).

In general, according to (ALTE) Association of Language Testers (2005), communicative competence development demands teaching the functional use of utterance in the context. As an English teacher in the Lebanese official school, I analyzed the textbooks according to their ability to develop pragmatic skills. My analysis showed that although awareness is attributed to the need of authentic input to achieve communication, but the reality in classrooms still do not meet the needs. There is also noticeable absence of the objectives and activities that teach the functional use of language. In addition, the books deal only with direct speech acts rather than indirect ones. Even more, the activities' goals are restricted only to one type of representatives. They aim to let the students either describe themselves, their feelings or others. There are also few activities that focus on directives (give offers, accept invitations, and give instructions). As we have seen, the other three functions (declaration, commissives, and expressive) are neglected although they are crucial to the development of the pragmatic competence as Searl (1969) revealed in his taxonomy. Accordingly, the learners can't understand the illocutionary meaning of the utterances in context, and these pragmatic problems hinder their communication.

As a result, the Lebanese students have pragmatic problems that prevent them from developing the high order thinking skills they need to master in doing reading, writing, listening and speaking activities. According to Tracy's (1999) checklist, the students have the following pragmatic problems. They are not able to tell a sequenced story, share appropriately in conversations, understand English idioms and jokes, understand and use nonverbal communication, use intonations, gestures, and body language appropriately, match between grammatical and functional use of utterances in spoken and written discourse, and use politeness markers appropriately.

\subsection{The Rationale of the Research}

English Language Learning nowadays is a prerequisite for every person. In this way, studying language in the social context is important not only to linguists, but also to sociologist, psychologist, business men , politician and translators. (Patel and Jain, 2008). Thus, this research is highly significant in EFL language teaching as it focuses on developing high order critical thinking skills in a new way.

This research is of great significance in language teaching and learning. EFL learners, in general, and Lebanese students in the official schools, in particular, will benefit from this research. Consequently, all EFL teachers and material designers can consider the results of this research, as a valuable input, to develop the pragmatic skills. It will help them to consider the importance of teaching the functional use of speech acts in contextual situations to design activities that develop the high order thinking skills to EFL learners. When EFL learners know the relevant use of speech acts in contextual situations, they will translate their ideas based on intentions not on word-to-word translation (Smith, 2003; Dina Alkilani ,2013). Teaching speech act also gives a new way to analyze and interpret meaning (Searl, 1969, 1983,2006).

In fact, many researchers have studied the effect of speech act theory on the development of language skills. However, this research adds new value of teaching speech acts in pedagogy because it emphasizes the importance of speech act to develop high order thinking skills. Thus, it contributes in the development of the learner's creativity in the four language skills: reading, listening, writing, and speaking. This helps the English language users to become proficient communicators and avoid miscommunication problems in the global community.

Overall, this research is significant as it focuses on helping EFL learners to be aware of speech act analysis to develop their analytical skills, and consequently they will use them to become more proficient when they communicate in English.

\subsection{The Research Questions}

Based on the above problem, this research is going to investigate these research questions:

$>$ To what extent can understanding the intended meaning of speech acts in contextualized situations develop the learners' high order thinking skills and contribute in developing their communication?

$>$ How can high order thinking skills increase the EFL learners' motivation to learn English as a second foreign language?

\subsection{The Research Hypotheses}

According to these questions, this research proposes the following hypotheses: 
$>$ Hypothesis 1: Analyzing the illocutionary meaning of speech acts in context will develop their EFL learners' high order thinking skills than the students who do not receive training.

$>$ Hypothesis 2: Students who use speech act appropriately and effectively in contextual situations will become more creative and motivated to communicate proficiently than students who didn't practiced this strategy.

\section{LITERATURE REVIEW}

The major purpose of EFL teaching is to equip the learners with basic skills that help them to communicate appropriately in the oral and written context. Communication is largely based on developing linguistic and pragmatic skills as well as it demands high order thinking skills that move learning gradually to creativity. Therefore, this research is going to investigate the speech act theory, its relation to high order thinking skills, and its application in EFL teaching.

\subsection{Speech Act Theory}

EFL teaching is based on two essential elements: linguistic competence and pragmatic competence. Halliday (1972) and Hymes (1973) said that learners should learn language not only linguistically, but also to achieve communicative goals. Acquisition of pragmatic competence becomes fundamental part of the communicative competence as it studies the relation between language use and its sociocultural rules (Bachman, 1990; Canale and Swain, 1980; Celce-Murcia 1995; Mc. Lean, 2004).

Speech Act theory is the bedrock of the pragmatic theory. Austin (1962) by added the term performatives as opposite to constatives. Constatives describe the utterance as true or false, while as performatives suggested that words can also perform action that can be true or false according to their felicity conditions. Furthermore, Austin distinguished between implicit and explicit performatives. Implicit performatives is the function expressed in the declarative and interrogative sentences while the explicit performative is several interpretation to one performative as in the imperative sentence.

Austin has also said that the function of the performative verb is determined by its felicity conditions: person, procedure, and circumstances of the utterance. Thus, Austin emphasized that words perform action, and this action can be classified into three acts: Locutionary act ( act of the uttered words), Illocutionary act(the function of the words uttered, what's done by the words such as thanking, apologizing, refusing), and Perlocutionary acts (the effect of the words on the listener that provokes him to action).

After that, Searle elaborated Austin's theory. Searle (1968) has reduced all the acts to the illocutionary act. Searle (1969) put his philosophy of language where he interpreted this act into three levels: the uttered word, the propositional act $\mathrm{P}$ (act of referring and predicting) and the illocutionary force $\mathrm{F}$ (the function of the words uttered). Searle (1969) illustrated that illocutionary act have these functions: declarations, representative, commisive, directives, and expressive. Searle (1969) has also illustrated that one act may have several functions. Thus, he discriminated between direct and indirect speech acts which means that there is difference between the surface meaning and the intended meaning.

Searle (1983) relied on his philosophy of language to put his theory of intentionality. He considered that speaker uses his intentions to capture an effect on the listener. Speaker and listener have shared conventions that enable them to capture the intended meaning. Searle (2006) tried to give the general characteristics of human language. He emphasized the relation of nonlinguistic behavior to linguistic intentionality.

In this way, we can say that we need to know the relevant use of speech acts to analyze critically and creatively the spoken or written discourse to be politely accepted in any speech community.

\subsection{Speech Act Theory and High Order Thinking Skills}

High order thinking skills are related to human's cognitive ability to think. During thinking, humans pass through stages that range from low to high levels of thinking. As figure one illustrated, Bloom's (1956) taxonomy put the cognitive thinking levels: knowledge, comprehension, application, analysis, synthesis and then evaluation. After that, Anderson and Krathwohl (2001) revised Bloom's taxonomy and arranged the levels of thinking by using action verbs: remember, understand, apply, analyze, evaluate and finally create.

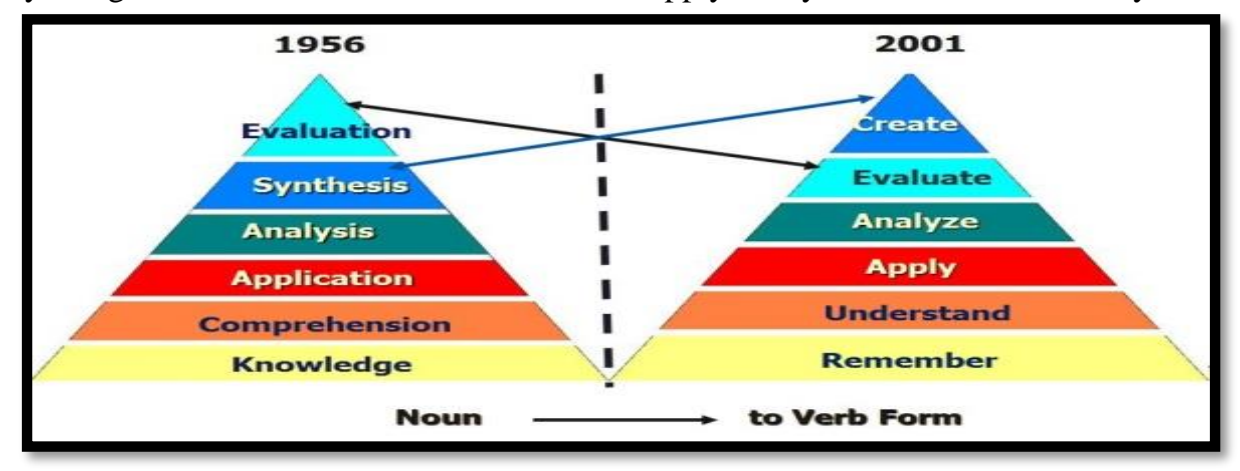

Fig. 2,1 High Order Thinking Pyramid

DOI Number: https://doi.org/10.30780/IJTRS.V04.I10.002

pg. 26

WWw.ijtrs.com

WwW.ijtrs.org 


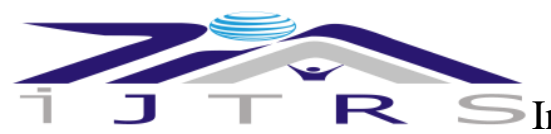

\section{International Journal of Technical Research \& Science}

Speech Act Theory is a worthy and valuable theory because it presents a new picture of analyzing meaning. The illocutionary act functions as presented in Searle's taxonomy are universal and applicable in all languages (Kasper and Rose, 2011). It corrected the earlier philosophical view as it analyzed meaning into propositional act and illocutionary force (Poythress, 2006). It also analyzed the meaning in a logical way (Oishi, 2006). Moreover, Moon (2002) also said that speech act analysis provides the learner with the sociocultural rules of the native speakers. Thus, the knowledge of the appropriate use of direct and indirect speech acts helps to achieve the politeness strategies that differ from culture to culture (Alemi and Irandoost, 2012).

Therefore, there's a wide relation between speech acts use and high order thinking skills. Rosenthal (2005) said that speech act use demands mental abilities and the state of being conscious which demands high thinking skills that lead to unconscious use of speech acts to fulfill the intended meaning. In this way, speech acts analysis allows understanding meaning in context. Thus, the performative function of direct or indirect speech act demands thinking of every word we want to speak which could develop critical analysis skills. Brookhart (2010) said that high order thinking skills could be classified into three categories: knowledge transfer (cognitive abilities), critical thinking skills (to reflect what they learned to make sound decisions), and problem solving( use the skills to solve real life problems).

Overall, speech acts use and high order thinking skills have a mutual relation. Understanding the meaning of speech acts and analyzing their meaning to be able to create a relevant and appropriate discourse demands development of high order thinking skills. In the same way development of high order thinking skills demands wide knowledge to the intentional meaning of the direct and indirect speech acts.

\subsection{Incorporating Speech Acts in EFL Teaching}

In general, humans are equipped with innate pragmatic skills. During the second language learning, students could predict these skills since some of them are universal. (Kasper and Rose, 2001). However, there are social and cultural differences. Mc Lean (2004) said that sometimes learners assume universality and lead to communicative problems. Therefore, it's advised to teach the appropriate function of speech acts to EFL learners to provide safe communication context (Xiujun, 2011). Teaching speech acts to EFL learners has many advantages.

First, it develops communicative competence. Speech acts analysis develop pragmatic skills, and hence earners achieve the communication goals (Cohen and Olshtain, 1990 and Kasper, 2006). Teaching the functional use of speech acts also develops the linguistic competence by helping the learners to perform the function they intend to master in a safe environment (Moon, 2002; Molina, 2011). Analyzing short stories pragmatically offers a good context to develop learners' critical analysis skills and foster their creativity ( Atikriti, 2011). Florida (1996) related higher order thinking to reading. Readers usually use high order thinking strategies to understand words from text such as make inferences from what is read, interpret diagrams, graphs, and statistical illustrations. In addition to that, Starkey (2000) said that critical discourse strategies enable the learners to be engaged in the text and feel confident to write about it. Moreover, the continuous use of the speech acts and their illocutionary meaning develops the learners' abilities in speaking Morrison (2012; Scholtz, 2012; Low, 2017; Neunar, 2003). Ibrahim (2008) has also revealed that critical interactive approach used the dialogue as useful strategy to raises the learners' intrinsic motivation in learning English. In this way, it's suggested to teach students the relevant use of speech acts in contextual and authentic tasks (roleplay, songs, videos, stories, emails) to develop the four language skills.

Furthermore, analysis of speech act develops high order thinking skills. Lavery (2001) said that to analyze texts in context, learners have to refer to: the field of the text (purpose, genre, subject topic), tenor of the text ( the relation between participants) and mode of the text ( the medium where it can be achieved). King et al. (1998) said that lessons involving higher order thinking skills require particular clarity of communication to reduce ambiguity and confusion and improve student attitudes about thinking tasks. They illustrated that lessons should be specifically designed to teach specific learning strategies. Teacher-student interaction should generate questions about novel problems and approaches followed by constructive feedback to inform the learners of their progress. It should also include challenging tasks that allow collaboration with students in other location to enable the learners use of appropriate utterance to build their skills in verbal analogies, logical thinking, and inductive/deductive reasoning. To develop high order thinking skills, teachers can generate questions using comprehension questions, explanatory questions, conclusion questions, predictions, deduction, and making inference (Killoran, 1992). Teaching high order critical thinking skills also demand specific strategies such as: compare- contrast, exemplify ideas, asking questions (Kou, 2006). Sugrue (1994) identified three response formats for high order thinking skills: selection (multiple-choice, matching), generation (short answer, essay, performance), and explanation (giving reasons for selection or generation of a response).

In addition to that, speech acts analysis develops the learner's creativity. Creative thinking is the highest level of thinking skills (Andirson and Krowthal, 2001). Bamiro (2011) had illustrated that relation between creativity and the use of verbal and nonverbal communication skills since correlating speech acts with appropriate situation is creative act. Thus, using tasks that require intellectual work and critical thinking increased student's achievement. Starkey (2000) said using critical discourse analysis strategy can help the learners to be engaged in the context and feel confident to discuss the issue, compare and contrast, and wrote on their feeling. 


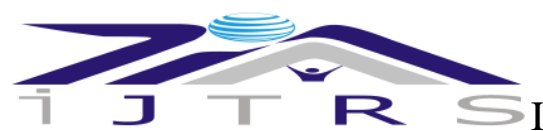

International Journal of Technical Research \& Science

Overall, incorporating teaching of speech acts in English language teaching is crucial. It fosters learners' linguistic and pragmatic skills, develop their high order thinking skills and fosters their creativity. Thus, this research is going to study this intimate relation between teaching speech acts and high order thinking skills to develop communicative competence to EFL learners.

\section{METHODOLOGY OF THE RESEARCH}

This research studies the effect of teaching the functional meaning of speech act on EFL learners on the development of their high order thinking skills. Thus, it adopts the experimental research design.

\subsection{Participants}

Sixty Cycle III students from the Lebanese official school with mean age fourteen years old shared in this experiment. They have studied English according to the Lebanese curriculum since their entrance to school. Then, they were divided randomly into control and experiment groups. I chose cycle III students because in this cycle, the learners practiced the basic thinking skills and strategies that they need in their education and reallife.

\subsection{Procedure}

The main aim of this study is to study the efficiency of teaching the functional meaning of speech acts to cycle II students to develop their creativity in receptive and productive skills. The procedure took around 50 periods, and it was divided into three stages:

Pre activities stage (pretests ): This stage was addressed to all the students. It considered as a diagnostic test to evaluate the learners' proficiency in written and spoken discourse in English language using critical and analytical skills (Brokhart, 2010).

Students $\backslash$ responded to two English tests that integrated the four language skills: First, students had five different authentic situations that were designed according to Searl's (1969) taxonomy. Students read them analytically and wrote a paragraph that describes the problem and suggested its appropriate solution. Second, the students watched video and filled in a dialogue completion activity. Then, students in pairs created their own dialogues and role-play them. These tests were corrected according to a specific checklist. Then, I took the average of the two tests to determine the learners' CEFR (2001) level.

During activities stage (Exploration and Learning stage): The students were divided randomly into two groups: control $(n=30)$ and experiment group $(\mathrm{N}=30)$. Only the students in the experiment group shared in this stage.

ALTE (2005) said that teachers can start with controlled practice activities and then move to free practice activities so that learners could focus on accuracy and fluency of the language taught. Thus, each activity moved from controlled practice stage to free practice stage. First, the students were introduced to speech acts in contextualized situations. They read texts and watched video scripts that discuss specific situation according to Searle's Taxonomy (1969). Then, the students analyzed and evaluated the functions of the direct and indirect speech acts used in the input material (Killoran, 1992; Florida DOE, 1996). After that, in the evaluation stage the learners creatively wrote paragraphs, composed songs, narrated stories sent emails, gave feedback, solved problems, practiced role-play, or presented posters and presentations using the intended speech act (Ibrahim, 2008; Sugrue, 1994; Alltiktiti, 2011; Kou,2006; \& Low (2017). Thus, these tasks developed the learners' high order thinking skills (Bamiro, 2011). They helped the learners to practice use of speech acts in input material (reading and listening) and then produce output materials (writing and speaking) (Molina, 2011, Kasper and Rose, 2011; Surgue, 1997). These tasks were adapted and edited from: Malíkova (2012), Copland et al., (2012), Lavery (2001), Jenkins (2001), Porto (2009), O' Conell (2009), Yates (2012) and British council learning English web site.

Table-2.1 Activities

\begin{tabular}{|c|c|c|c|}
\hline Activity & Objective & Procedure & Time \\
\hline $\begin{array}{ll}\text { 1. How to } \\
\text { Greet } \\
\text { someone }\end{array}$ & $\begin{array}{l}\text { To practice } \\
\text { declarations }\end{array}$ & $\begin{array}{l}\text { Watch video, Analyze speech acts of greeting, } \\
\text { Roleplay dialogue }\end{array}$ & $\begin{array}{l}4 \\
\text { periods }\end{array}$ \\
\hline 2. Inviting & $\begin{array}{ll}\text { To } & \text { practice } \\
\text { directives }\end{array}$ & $\begin{array}{l}\text { Watch video, Analyze speech acts of inviting, } \\
\text { accepting and refuse, Write invitation cards }\end{array}$ & $\begin{array}{l}4 \\
\text { periods }\end{array}$ \\
\hline 3. Eating Out & $\begin{array}{l}\text { To practice } \\
\text { commisives }\end{array}$ & $\begin{array}{l}\text { Read a text, Analyze speech act of offering, accepting, } \\
\text { complementing and suggestions, Write signs, } \\
\text { Roleplay dialogue }\end{array}$ & 4periods \\
\hline 4. House Seller & $\begin{array}{l}\text { To practice } \\
\text { commisives }\end{array}$ & $\begin{array}{l}\text { Read advertisement, Analyze speech acts of offering, } \\
\text { asking, and describing, Write email to buy the house, } \\
\text { Receive feedback }\end{array}$ & $\begin{array}{l}4 \\
\text { periods }\end{array}$ \\
\hline $\begin{array}{l}\text { 5. The Mad } \\
\text { Gardener's } \\
\text { Song }\end{array}$ & $\begin{array}{l}\text { To practice } \\
\text { Expressive }\end{array}$ & $\begin{array}{l}\text { Listen to song, Discuss its meaning, Write a song to } \\
\text { express your feeling }\end{array}$ & $\begin{array}{l}4 \\
\text { periods }\end{array}$ \\
\hline
\end{tabular}

DOI Number: https://doi.org/10.30780/IJTRS.V04.I10.002

pg. 28

www.ijtrs.com

www.ijtrs.org 


\begin{tabular}{|c|c|c|c|}
\hline 6. Mc Gee & $\begin{array}{l}\text { To practice } \\
\text { descriptive }\end{array}$ & $\begin{array}{l}\text { Read a story, Analyze the speech act of describing, } \\
\text { Describe a person and present your description by } \\
\text { poster. }\end{array}$ & $\begin{array}{l}4 \\
\text { periods }\end{array}$ \\
\hline $\begin{array}{l}\text { 7. Goldilocks } \\
\text { and the three } \\
\text { bears }\end{array}$ & $\begin{array}{l}\text { To practice } \\
\text { Politeness rules }\end{array}$ & $\begin{array}{l}\text { Read a story, Analyze speech act, Write your own } \\
\text { story }\end{array}$ & \\
\hline $\begin{array}{l}\text { 8. Garbage } \\
\text { Crisis in } \\
\text { Lebanon }\end{array}$ & $\begin{array}{l}\text { To practice } \\
\text { Problem solving }\end{array}$ & $\begin{array}{l}\text { Read newspaper article, Analyze the problem, Write a } \\
\text { letter to ministry of environment to suggest solution. }\end{array}$ & $\begin{array}{l}4 \\
\text { periods }\end{array}$ \\
\hline 9. Debate & $\begin{array}{l}\text { To Express } \\
\text { agreement/ } \\
\text { disagreement }\end{array}$ & $\begin{array}{l}\text { Watch video script, Analyze speech acts, Debate } \\
\text { (Card Game) }\end{array}$ & $\begin{array}{l}4 \\
\text { periods }\end{array}$ \\
\hline $\begin{array}{l}\text { 10. Japanese } \\
\text { culture }\end{array}$ & $\begin{array}{l}\text { To practice } \\
\text { politeness rules }\end{array}$ & $\begin{array}{l}\text { Watch a video, Criticize the unusual behavior, Write } \\
\text { poster to compare and contrast between our own } \\
\text { culture and Japanese culture }\end{array}$ & $\begin{array}{l}4 \\
\text { periods }\end{array}$ \\
\hline
\end{tabular}

Post activities stage (Evaluation Stage): It was the assessments stage. First, the learners were exposed to two tests( writing and speaking) that have the same objectives as in pre stage. They were assessed quantitatively by the same checklists in order to assess how far the learners had progressed. Second, the learners responded to an open questionnaire that evaluated qualitatively their attitudes and motivation towards the activities used in the experiment.

Therefore, these activities achieved the general objectives of the Lebanese curriculum as they integrated the four language skills, and presented the cultural and social interaction (Lebanese association, 2003). They also enabled the learners to take risks to communicate and interact with their peers, as well as it helped them to be autonomous learners. In addition to that, these activities emphasized the importance of drama techniques to develop the pragmatic skills to EFL learners. (Lavery, 2011 and ALTE , 2005). They also had a wide variety by using different materials (pictures, films, texts, songs, questionnaires ....). (Baker and Westrup, 2000). They suited all learners styles (visual, auditory, kinesthetic), and way of interaction (individual, pair and group). Thus, these activities took into consideration the learners' needs.

\section{RESULTS AND ANALYSIS}

Actually, the major purpose of EFL teaching is to help EFL learners to communicate appropriately. The qualitative and quantitative analysis to the results revealed the efficiency of teaching the functional use of speech acts on developing high order thinking skills.

The quantitative analysis are represented in the following bar graphs. The pretest results (fig. 4.1) showed that $90 \%$ of the students were on A1 level, 7\% A2 and 3\% B1 level. The posttests results (fig. 4.2) revealed that the students in the experiment group A1 decreased to 5\%, A2 level increased to $80 \%$ and B1 level increased to $18 \%$. Therefore, teaching students how and when to use relevant speech acts in appropriate contextual situations developed their communicative skills as the result of the development their high order thinking skills.

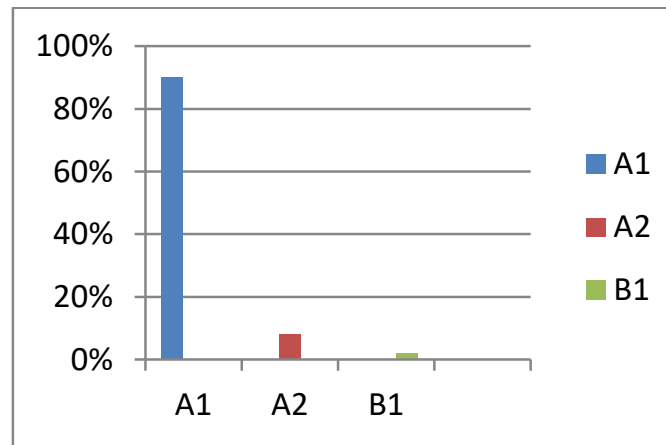

Fig. 4.1 Pretest Results

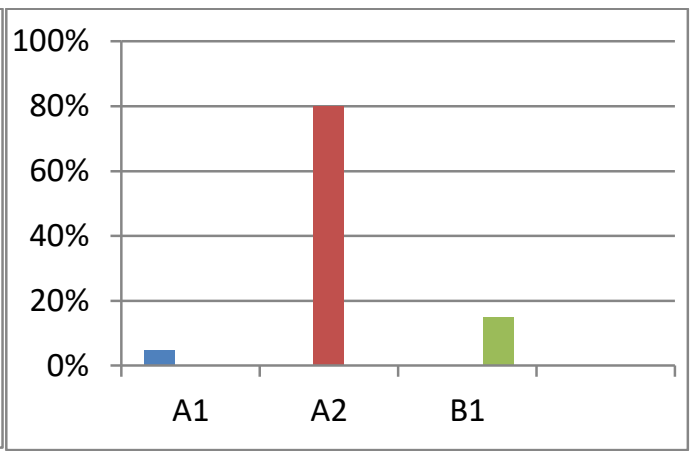

Fig. 4.2 Post Tests Results

Therefore, these results affirmed the first research hypothesis which stated that:

Hypothesis 1: Analyzing the illocutionary meaning of speech acts in context will develop their EFL learners' high order thinking skills than the students who do not receive training.

The qualitative results to the open questionnaire revealed that most of the students liked the activities and became more interested in learning English. This result affirmed the second research hypothesis which stated that:

Hypothesis 2: Students who use speech act appropriately and effectively in contextual situations will become more creative and motivated to communicate proficiently than students who didn't practiced this strategy. 


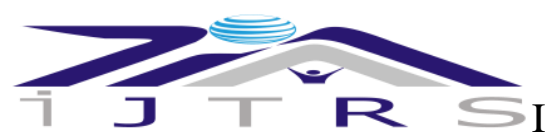

\section{International Journal of Technical Research \& Science}

As a result, we can say that the results affirmed the two research hypotheses. Hence, this research added a piece of puzzle to the effectiveness of functional teaching of relevant speech acts to EFL learners to develop their high order thinking skills and communicate more proficiently in authentic situations.

\section{CONCLUSION}

High order thinking skills development is a basic element that help EFL learners to communicate proficiently. Speech act analysis could help them to receive the text in an analytical way and produce creative written and oral speech. However, investigating Lebanese EFL curriculum revealed the absence of developing pragmatic skills and consequently it affects negatively on their communicative skills. The students didn't given the opportunity to use high order analysis skills to analyze and evaluate the speech acts used in the input materials to help them creatively produce output materials. To solve this problem, this research affirmed that teaching the functional meaning of speech act in contextualized situations to EFL learners could develop high order critical analysis skills. Hence, their linguistic and communicative abilities will be progressed and consequently increase their creativity and motivation to learn English as a second language.

This research had investigated the effect of high order thinking skills on developing communication and increasing learners' motivation to learn. Thus, the results answered the two research questions.

First, speech act theory was incorporated in purposeful activities that aim to help EFL learners to analyze, observe, compare, contrast and use their creativity to communicate. Thus, the pre/ post tests results answers the first research question:

Q 1. To what extent can understanding the intended meaning of speech acts in contextualized situations develop the learners' high order thinking skills and contribute in developing their communication?

The pre and post tests revealed that teaching the functional use of relevant and appropriate speech acts has many advantages. It developed the learners' linguistic and pragmatic competence. Speech act teaching introduced the learners to new vocabs and grammatical structures that develop their linguistic and pragmatic competences. In addition to that, focusing on analyzing speech acts enabled the learners to use speech acts unconsciously and automatically in contextualized situations. This reduced the conflict that result from misunderstanding of the speech acts used in intercultural communication.

The pre test results asserted the need for teaching speech acts in contextualized situation. This affirmed Kasper and Rose (2001) and Mc Lean's (2004) conclusions that people learn most of second language pragmatic knowledge free but they didn't capitalize on their previous pragmatic skills during language learning. Hence, speech acts should be taught to avoid the miscommunication problems that come from cultural differences since learners do not get access to their pragmatic skills (Xiujun, 2011; Tatsuki and Houck, 2010).

The post test result affirmed the efficiency of teaching speech acts in developing communicative competence as a result of using high order thinking skills. what Moon (2002) and Molina (2011) have said that learners should practice the use of speech acts in authentic situations in order to help them master the function they learned. In addition to that, teaching the functional meaning of speech acts in authentic situations developed the learners' high order thinking skills to become proficient communicators in English. This also affirmed King et al. (1998) conclusion that high order thinking skills are developed by communication. It also affirmed what Kou (2006) said that high order thinking skills are related to specific strategies that demand analysis of speech acts. Moreover, it affirmed that teaching speech acts develop high order critical thinking in reading, writing, listening and speaking (Ibrahim, 2008; Florida ,1996; Surgue, 1996; Scholtz, 2012).

Furthermore, through studying speech act function in purposeful activities, the students' creativity was revealed. This motivates them to participate more to learn English which answers the second research hypothesis:

Q 2. How can high order thinking skills increase the EFL learners' motivation to learn English as a second foreign language?

The questionnaire analysis revealed that speech act analysis contributed in raising the learners' awareness towards their high order thinking skills. The authentic activities gave the learners the opportunity to build their self-confidence and increase their intrinsic motivation to learn English in a creative environment. Furthermore, teaching speech acts in group work activities developed the learners' team collaboration in the social life.

These results affirmed Anderson and Krathwohl (2001) who put creativity at the top of thinking skills' pyramid. It also goes along with Florida (1996) who related reading comprehension motivation to higher order thinking by interpreting diagrams, graphs, and statistical illustrations to understand the written words. In addition to that, it goes along with Starkey (2000) who affirmed the relation between said that critical discourse strategies that help learners to feel confident to write. Moreover, these results affirmed that analyzing speech acts develop speaking skills (Morrison, 2012; Scholtz, 2012; Low, 2017; Neunar, 2003; Ibrahim, 2008). It also asserted Bamiro (2011) who had asserted that the use of verbal and nonverbal communication skills increase the learners' creative skills. the results also go along with Starkey (2000) who said using critical discourse analysis strategy help the learners to be engaged in the context and feel confident to discuss the issue, compare and contrast, and wrote on their feeling.

As the qualitative and quantitative results affirmed the two research hypotheses, this research adds a piece of puzzle to EFL teaching in the behalf of speech act and high order thinking skills. Thus, it is recommended to be applied in the Lebanese EFL curriculum. Teaching the functional meaning of speech acts in contextualized 


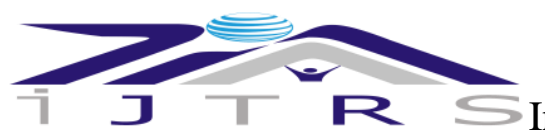

\section{International Journal of Technical Research \& Science}

situations enable the Lebanese students to develop their high order critical analysis skills and be more able to analyze, evaluate and create spoken and written discourse. This enables the Lebanese learners to be proficient communicators, and thus they become more opened, flexible and go from national to global citizens.

Finally, people should be equipped with communication tools to confront the cultural invade in the global world. Thus, with the progress of globalization and internationalization, a further research is needed to analyze the effect of speech acts on shaping people's thought and behavior through mass media.

\section{REFERENCES}

[1] Alemi, M. and Irandoost, R. (2012,). A textbook evaluation of speech acts the case of English result series. International Journal of Applied Linguistic and English Literature .Vol. 1 No. 6.

[2] Alkilani, D. (2013). Perspectives on English in the Middle East and North Africa: A Research Initiative part of the British Council's English for the Future Programme in MENA. London: British Council.p17

[3] ALTE (Association of Language Testers in Europe). (2005). TKT.Teacher's Knowledge Test. ESOL Examination: Cambridge.

[4] Al Zoughbi, I . (July, 31, 2013). Assessment of Lebanese Curriculum for 3 years. Al Safir Newspaper: Lebanon.

[5] Anderson, L. W. and Krathwohl, D. R.(Eds.) (2001) A Taxonomy for Learning Teaching, and Assessing: A Revision of Bloom's Taxonomy of Educational Objectives. Allyn \& Bacon. Boston, MA (Pearson Education Group)

[6] Austin, J. (1962). How To Do Things with Words. The Clarendon Press: Oxford.

[7] Ayash, A. (2016). Teaching in Lebanon is Dissatisfying. AlNahar, 10 , December, 2016.

[8] Bachman, L. (1990). Fundemental Considerations in Language Testing. New York: Oxford University Press (p.p. 81-110).

[9] Bamiro, E. (2011). Transcultural Creativity in World Englishes: Speech Events in Nigerian English literature. Mowe, Ogun State, Nigeria: Redeemer's University.

[10] Baker, B. \& Westrup, H. (2000) The English Language Teacher's Handbook: How to teach large classes with few resources. London: Continuum.

[11] Brookhart, Susan (2010). How to Assess Higher-Order Thinking Skills in Your Classroom. Ascd Store.

[12] Bloom, B.S. and Krathwohl, D. R. (1956) Taxonomy of Educational Objectives: The Classification of Educational Goals, by a committee of college and university examiners. Handbook I: Cognitive Domain. NY, NY: Longmans, Green.

[13] British Council.learn English retrived 11, January 2017 from:http://learnenglish.britishcouncil.org/en/howto

[14] Canale, M. and Swain, M. (1980). Theoretical Bases of Communicative Approaches to Second Language Teaching and Testing. Applied Linguistics Oxford University Press. (pp. 1- 47).

[15] Celce-Murcia, M. (1995). Rethinking the Role of Communicative competence. Intercultural Language Use and Language Learning. USA: University of California . (pp. 41-57).

[16] CEFR (2001). Common European Framework of Reference. Council of Europe. Cambridge English.

[17] Crystal, D. (2003). English as a global language. (2nd ed) Cambridge : Cambridge University Press.

[18] Cohen, A. and Olshtain, E. (1990). The Learning of Complex Speech Act Behaviour. TESL Canada Journal, Vol. 7. no.2, March 1990.(pp.45-65).

[19] Copland, F. (2012). Crazy Animals and Other Activities for Teaching English to Young Learners. London: British Council.

[20] The English Language Curriculum in Lebanon.(1997). Retrieved Dec, 2019 from http://www.crdp.org/crdp/all\%20curriculum/English/English\%20language\%20curriculum.pdf

[21] Florida (DOE). (1996). Retrieved January, 2018 from http://www.flsenate.gov/reports.

[22] Ghaith, G. and Shaaban, K. (1999). The New Curricula in Lebanon: Evaluative Review. Chapter 15: The Prospects and Problems of the New Lebanese English Language Curriculum. Lebanon: Lebanese Association for Educational Studies.

[23] Halliday, M.A.K (1973). Being and Work. Chart TESL (Ed.). (January 28, 2011).

[24] Hymes, D.H. (1972). On Communicative Competence. In J.B. Pride and J. Holmes (Eds.), Sociolinguistics London: Penguin. (pp. 269-293).

[25] Ibrahim, N. (2008).Children's Literature for Second Language. Beirut: The Lebanese University Publication.

[26] Jenkins, H. (2001) .Teaching Materials from the Literature Department of the British Council: Starting to Teach Creative Writing in The English Language Classroom. London: British Council.

[27] Kashru and Smith.(2008).Cultures, Context, and World Englishes. ESL and Applied Linguistics Professional Series. New York and London: Routledge.

[28] Kasper , G. and Rose, K. (2001). Pragmatics in Language Teaching. Cambridge University Press.

[29] Kou, Xiojing ( 2006). Distance Learning. An Official Publication of the United State Distance Learning Association.Volume 3. 


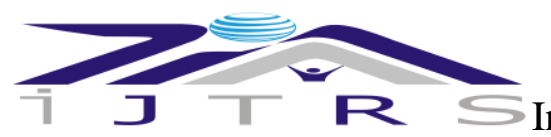

International Journal of Technical Research \& Science

[30] King ,FJ, Goodson ,Ludwika, and Rohani,Faranak(1998). High Order Thinking Skills. Educational Survive Program.

[31] Killoran, J. (1992). In defense of the multiple-choice question. Social Education. 56(2).pp(106-108).

[32] Kothari,C.R. (2004).Research and Methodology. Methods and Techniques. $2^{\text {nd }}$ ed. New Age International (P) Ltd., New Delhi: Publishers.

[33] Lavery, Clare (2001). Language Assistant. England: The British Council.

[34] Lebanese Association for Educational Studies.( 2003). Evaluative Study of the Educational Curriculum in Lebanon. Retrived Feb, 15,2018. http://www.laes.org/_publications.php?lang=ar\&id=36

[35] Malíková, D. ( 2012 ). A Practical English Handbook For Bachelor Students. Retrieved March 22, 2013 , from: www.scribd.com/doc/94775488/Practical-English.

[36] Mc Lean, T. (2004).Giving the Students a Fighting Chance: Pragmatics in Language Classroom. TESL Canada Journal, vol. 21, no 2, 72- 92.

[37] Molina, P. (2011). Designing Teaching Materials for the Development of Conversation: The use of films in online environments. Universidad De Granada.

[38] Moon, K. (2002). Differences Between Native And Nonnative Speaker Complaint Strategies. The American University .Retrieved March 18,2018, from: http://www.american.edu/cas/teso 1/pdf/upload/WP2002-Moon-Speech-Act.pdf.

[39] Morrison, K. ( 2012). School Leadership and Complexity Theory. Routledge Neunar, G .(2003). Sociocultural interim worlds in foreign language teaching and learning. Intercultural Competence. In Byram (ed.). Council of Europe. Strasbourg classroom. Cambridge, UK: Cambridge University Press.

[40] O'Conell, (2009) Britlit. Using Literature to teach EFL. British Council.

[41] Oishi, Etsuko ( 2006). Austin's Speech Act Theory and the Speech Situation. Retrieved Dec, 2018:http://www.univ.trieste.it/ eserfilo/art106/oishi106.pdf

[42] Oxford Dictionary (2016). Retrieved December 2018 from: http://www.ebay.co.uk/itm/Oxford-AdvancedLearners-Dictionary-Paperback-DVD-Premium-OnlineAccess/361720012169?hash=item5438315d89:g:YgcAAOSwFnFV8GIX

[43] Patel and Jain.(2008). English Language Teaching (Methods, tools and Techniques). Sun Rise Publishers and Distributers.

[44] Porto, F. (2009, August). BritLit: Using Literature in EFL Classrooms. London: British Council.

[45] Poythress, S. (2008). Canon and Speech Act: Limitations in Speech-Act Theory with Implications For a Putative Theory of Canonical Speech Acts. Westminister Theological Journal. 70 pp.337-54.

[46] Rosenthal, D. ( 2005 ). Consciousness and Mind. Oxford University Press.

[47] Rubin, D. (2000). Teaching Elementary Language Arts: A Blanced Approach. USA: Library of Congress Cataloging.

[48] Searle, J. (1968). Austin on Locutionary and Illocutionary Acts.The philosophical Review. Duke University PressVol.77.No. 4.(p.p. 4o5-424).

[49] Searle, J. (1969). Speech Acts. An Essay on the Philosophy of Language. Cambridge ch.1, 2, 3 \&5.

[50] Searle, J.(1983). Intentionality: An Essay in the Philosophy of Mind. Cambridge, England: Cambridge University Press. (Vol. 9).

[51] Searle, J. (2006). What is Language: Some Preliminary Remarks. German Philosophy Conference in Berlin, Kreativität.

[52] Scholz, R. W., \& Tietje, O. (2002). Embedded Case Study methods: Integrating quantitative and qualitative knowledge. Thousand Oaks: Sage Publications.

[53] Smith, Barry (2003). John Searle : From speech acts to social reality. Retrieved April 17, 2017 from http://www. google.com.lb/books? isbn $=0521797047$.

[54] Starkey, H. (2000), Human Rights. In: M. Byram (ed.) Encyclopedia of Language Teaching and Learning. London: Routledge.

[55] Sugrue, B. (1994). Specifications for the Design of Problem Solving Assessments in Science (CSE Technical Report 387). Los Angeles: CRESST/University of California.

[56] Tatsuki, D,\& Houck. ( 2010 ) Pragmatics: Teaching Speech Acts . In Dantas, Maria et al. (Ed). USA :TESOL Classroom Practice Series. Ch.1 and 6.

[57] Tracy, J. (1999). Pragmatic Skills Checklist. Retrieved April 17, 2019, from http://www.jtc.org/uploads/docs/Pragmatic_Skills_Checklist.pdf

[58] Xiujun, S. (2011). Application of Speech Act Theory to Oral English Training in the ESL Classroom. Platteville: University of Wisconsin.

[59] Yates, J. (2012). English Conversation. America: McGraw-Hill Companies. 